Irina B. Pavlova

Doctor of philology

Senior researcher

Institute of World Literature

Russian Academy of Science

e-mail: antologia1@yandex.ru

Russia, Moscow

ResearcherID AAO-8719-2020

ORCID 0000-0002-0006-0156

\title{
THE IMAGE OF A VICIOUS CIRCLE IN MIKHAIL SALTYKOV-SHCHEDRIN'S ART WORLD
}

Summary: The article examines the image-symbol of a vicious circle in the work of the social satirist M. E. Saltykov-Shchedrin. This image, plays an important role in creating a picture of the Russian national world. The circle embodies integrity, continuity, initial perfection and - hopelessness, fate, dead end. In the works of the satirist, the image-symbol of a vicious circle carries the meaning of stagnation, lifelessness, denial of the future, mysterious predestination. With regard to the social sphere, this image-symbol was used in the $19^{\text {th }}$ century. French socialist-utopian Charles Fourier in his work "The New Economic and Societal World, or the Invention of a Method of Attractive and Naturally Appropriate Labor Distributed in Series of Passions", a representative of the radical democratic wing in Russian journalism D.I. Pisarev (article "Realists"). In the works of Saltykov-Shchedrin, the idea of a vicious circle appears repeatedly. The satire "The History of a City" testifies that the despotic forms of government, replacing one another, the power of the reactionary dark forces are a kind of fate for the country and the people. The existence of representatives of the local nobility, the popular masses, moves in a vicious circle,

We call Saltykov-Shchedrin the writer of "bitterness and anger". A researcher of the satirist's work, S. Makashin, wrote: "with the totality of everything they wrote, each of Russia's great writers created their image, their own single and integral picture of their native country and people. $\langle\ldots\rangle$ All these and many other Russias were a reality. They existed and coexisted. Rising from the pages of most of his works, the gloomy, tragic Russia of Saltykov or, better to say, Shchedrin coexisted together with marked by stagnation, hopelessness, emptiness, and lack of hope for the future. The same can be said about the situation in the Russian outback: there only meaningless repetitions of events, the renewal of identical phenomena are possible. The conservative-protective desire to mythologize history, an apology for absolutism, is fraught with the danger of distorting the meaning of history, its driving forces, denying the centuries-old trials that have befallen the country and the people. For Saltykov-Shchedrin, the image of a vicious circle is associated with the riddle of Russian national destiny, which he has been trying to comprehend over the years. Striving for the ideal of social harmony, overcoming the vicious circle of predetermination for the enlightener, moralist was associated with both social transformations and moral renewal of the individual, with the awakening of Shame, Conscience and Truth in an individual and in the whole society, with their spiritual transformation, which gives an opportunity to make a breakthrough, initiate a purposeful life-giving movement forward.

Keywords: satire by Saltykov-Shchedrin, vicious circle, the fate of Russia, spiritual transformation.

them..." ${ }^{1}$. When depicting it, the artist often turned to the image-symbol of a vicious circle.

The meaning of the expression circulus vitiosus (Latin): a logical error or trick in which a statement is concluded from itself, usually through several intermediate statements. The expression has become a phraseological unit.

1. Makashin S.A. Saltykov-Shchedrin. The Middle of the Way. The 1860s-1870s. Biography. Moscow: Hudojestvennaya Literatura, 1984. 


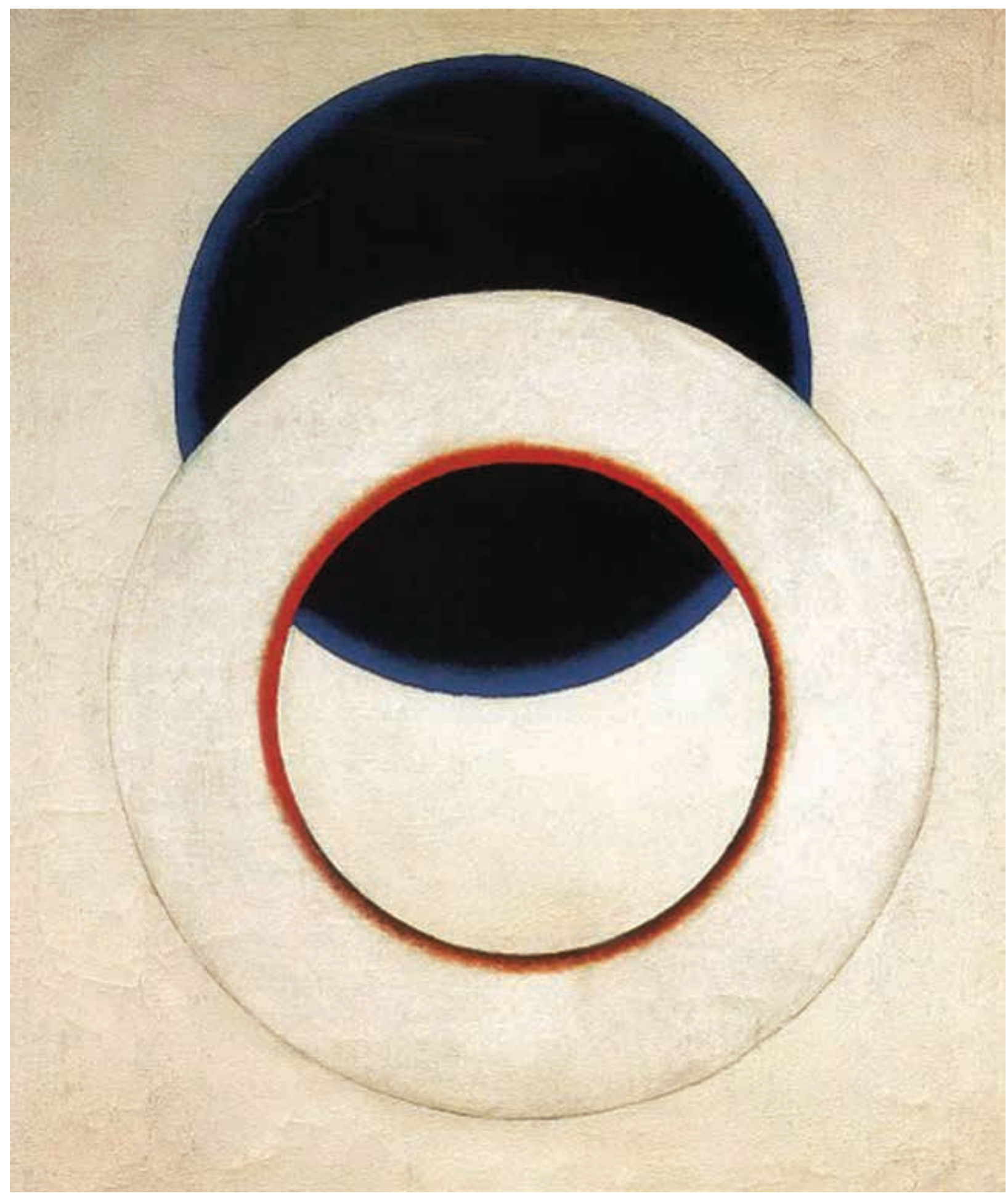

III. 1. Alexander Rodchenko. 1918. White Circle

A circle, a universal symbol found in many world cultures and religious systems, accompanies humankind's entire history. It contains the idea of movement, time, and space. A circle is ambivalent: it symbolizes integrity, continuity, initial perfection and hopelessness, fate, a dead-end, insoluble situation.

In the phraseological dictionary of the Russian language, the expression "vicious circle" is explained as follows: "The word vicious (from vice) correlates with the religious and moral code of culture, that is, with a set of moral attitudes and ideas, in which vice acts as something shameful and reprehensible, which gives rise to a negative assessment in the figurative content of a phraseological unit.

As a whole, the phraseological unit denotes a stereotypical idea of the hopelessness of a combination of circumstances, of the impossibility of finding a way out of the current situation. 
Other European languages have similar figurative expressions; for example, in French - cercle vicieux, in English - a vicious circle." ${ }^{2}$

The article will discuss the use of this image in social satire.

It should be noted that in Russian literature and journalism of the $19^{\text {th }}$ century, not only SaltykovShchedrin used the image-symbol of a vicious circle. For example, in the article "Realists" (1864), his contemporary, "radical commoner" Pisarev, had an aphorism that became a popular expression: "...we are poor because we are stupid, and we are stupid because we are poor. The snake bites its tail and represents an emblem of eternity, from which there is no way out. Charles Fourier says quite rightly that the main force of all the calamities of modern civilization lies in this damned cercle vicieux." " meant the work of the French utopian socialist, "The New Economic and Societal World, or The Invention of a Method of Attractive and Naturally Appropriate Labor, Distributed in Series of Passions" (1829). Fourier stated that the fact that poverty is born of abundance is the vicious circle of bourgeois civilization. As a way out of the cercle vicieux, he proposed creating large-scale production, the development of science and art, which would help to end poverty and ignorance.

As mentioned above, this image is important in Saltykov-Shchedrin's formation of the concept of the Russian world.

The grotesque The History of a Town occupies an exceptional place in Russian classical literature. The town of Glupov is a symbol of all Russia "taken in the denunciatory thickening of its reactionary forces and dark sides, its 'historical evil', poured out in the whole 'nature of things'" 4 . The satire's eschatological finale is associated with the destruction of time, with the "end". The work ends with the words: "History has stopped its course" 5 . However, there is Ugryum-Burcheev's "prophecy": "Someone is following me, and he will be more terrible than

2. Zaharchenko I. V. Phraseological Dictionary of the Russian Language // Big Phraseological Dictionary of the Russian Language. Meaning. Use. Culturological Commentary. Executive editor V. Telia. Moscow: AST-Press Kniga, 2006.

3. Pisarev D.I. Full collection cit.: in 12 volumes. V. 6. Moscow, 2003,. P. 224.

4. Makashin S. A. Saltykov-Shchedrin. The Middle of the Way. The 1860s-1870s. Biography. Moscow: Hudojestvennaya Literatura, 1984.

5. Saltykov-Shchedrin M. E. Collection of Works in 20 Volumes V. VIII. Moscow: Hudojestvennaya Literatura. 1969. P. 423. Later, references to this edition are presented in the text with an indication of the volume and page in parentheses. me", as well as the list of city governors. After the disappearance of the fanatical nivilator, PerehvatZalihvatsky enters the city on a white horse, as a winner; he burns down the gymnasium and abolishes science. That is, everything goes back to square one.

Described in the early story "Contradictions", in many satirical cycles, in the chronicle Poshekhonskaya Starina, the existence of the local nobility as well as the life of the Russian hinterland, of countless provincial towns, which, according to M. Bakhtin, are "a place of cyclical everyday life", follow the movement in a vicious circle. "There are no events here; only repetitive 'existence'. Here, time is deprived of a progressive historical course, it moves in narrow circles $<\ldots\rangle^{\prime \prime}{ }^{6}$. Boredom, hopelessness, lack of a living, and active beginning prevail everywhere.

In several works, Saltykov-Shchedrin expressed an idea that the mythologization of absolute power by conservative and protective representatives of the "state" or "liberal" historical schools turns into falsification; it means the denial of centuries of grievous suffering, trials, befallen the motherland and its future. In the story "Children of Moscow", he puts the following words into the lips of the hero-narrator, who recalls the years spent in an elite educational institution: "Russia seemed to me to be a deposit of fabulous knights, 'beautiful, proud, dignified', and its story was some radiant circle in which reigns succeeded each other, leaving nothing behind but glory" (XII, 372).

Hopelessness also determines the life of the masses. In the chronicle Our Social Life, February 1864, the mythological image of the inexorable time - Saturn, makes the hopeless picture of the life of the people especially impressive: "Like a leaden canopy, impenetrable darkness has bristled up over these huts and is heavy; and in this darkness, old Saturn reigns supreme, devouring his children alive". The son is an eternal witness to the silent cowardice or cowardly craftiness of his father. Can he learn anything else from his observations except his cowardice and craftiness? Can the son, accustomed to seeing from his mother's nipples that everything around him obeys blind chance, without making the slightest attempt to free himself from her yoke, have anything other than boundless faith in the same blind chance? Thus, it, this darkness, passes from one generation to another, more and more abruptly securing the

6. Bakhtin M.M. "Forms of Time and Chronotope in the Novel" // Matters of Literature and Aesthetics. Moscow: Hudojestvennaya Literatura, 1975. P. 396. 
damned snares, which they are tangled in" (VII, 267268). Saltykov-Shchedrin often imagined that Russian life was fatalistically moving in a vicious circle, which was unknown how to break, and that the oppression of age-old prejudices was getting worse.

The image of a vicious circle in Shchedrin's ideological and artistic concept is associated with the mystery of national fate. The world that appears in Saltykov-Shchedrin's works is extremely contradictory, disordered; cause-and-effect relationships are tangled. Everything indicates that its comprehension and transformation require significant efforts. The satirist writer's reflections on this topic are colored with deep anxiety, full of bitterness, indignation. Severe criticism is not only a feature of SaltykovShchedrin's mind; it was generated by many facts and phenomena of the contemporary artist's reality. "Doesn't such a social structure," he poses the question in his works, "represent a hopeless circle, so to speak, in which identical phenomena are constantly renewed, without any hope of ever being resolved?" (V, 372). In this vicious circle, Russia is struggling and cannot break free. In the work of the satirist, the homeland and the people appear to be invariably suffering from "contradictions" and "complicated affairs", "misfortunes", "dark witchcraft".

Throughout his creative life, the satirist-writer looked for ways to overcome a mournful lot of his country. The idea of personal and collective responsibility for the future of Russia is constantly present in his works. The author clearly understood the full force of empirical evil, socio-historical circumstances, the imperfection of the "nature of things". An educator, social moralist, Saltykov-Shchedrin, who worked in the $1850 \mathrm{~s}-1880$ s of the $19^{\text {th }}$ century, tirelessly sought an opportunity to break the vicious circle of predetermination. Therefore, his work's ideal setting was focused on awakening Shame, Conscience, and Truth in people and society on their spiritual transformation, which would allow making a breakthrough to initiate a purposeful life-giving movement forward. The satirist artist firmly believed: in order to solve the riddle of Russia, "you need to pick up a staff, tie a belt around your waist" and "go forward, seeking a better city" (XIII, 285), as it is said in the cycle Mon Repos Shelter (1878-1879) about the relentless striving for social harmony and the highest ethical values.

\section{REFERENCES}

1. Bakhtin, M. M. 1975. "Forms of time and chronotope in the novel", Questions of literature and aesthetics. Moscow, pp. 234-407.

2. Danilova, A. I. 2012. "Archetypal image of a circle in Russian literature", Novorossiysk branch of the GOU VPO "Pyatigorsk state. Linguistic University, no. 2, pp. 271-274.

3. Wakashan, S. A. 1984. Saltykov-Shchedrin. The middle of the way. 1860s-1870s. Biography. Moscow

4. Pisarev, D. I. 2003. Full collection cit.: in 12 volumes, vol. 6. Moscow

5. Reznikova, E. V. 2016. "The dynamic aspect of the concept "circle": the experience of structuring on the basis of an image-scheme", Bulletin of the Samara State. University. History, pedagogy, philology. Samara nat. Research un-t them. Acad. S. P. Queen. Samara, no. 3-2, pp. 162-165.

6. Saltykov-Shchedrin, M. E. 1965-1977. Coll. Vol.: in 20 volumes. Vol. V, VII, VIII, XII, XIII. Moscow.

7. Saraeva, E. L. 2014. "Reflections of P. Ya. Chaadaeva about the fate of Russia", Yaroslavl Pedagogical Bulletin, no. 4, vol.1, pp. 17-26.
8. Phraseological Dictionary of the Russian Language, Big Phraseological Dictionary of the Russian Language. Value. Use. Culturological commentary, executive editor V. N. Telia. Moscow, 2006.

9. Pavlova, I. B. 2020. "The Color Symbolism in the Works of M. Saltykov-Shchedrin", Art Literature Scientific and Analytic Journal Burganov House. The Space of Culture, vol. 16, no. 2, pp. 91-99. DOI:10.36340/2071-68182020-16-2-91-99

10. Gerschenkron, A. 1975. Time Horizon in Russian Literature. Slavic Review, 34(4), 692-715. DOI: $10.2307 / 2495723$

11. Lounsbery, Annoncee. "In the End: Shchedrin, Sologub, and Terminal Provinciality. », Life Is Elsewhere: Symbolic Geography in the Russian Provinces, 1800-1917, 229 42. Ithaca; London: Cornell University Press, 2019. Accessed March 22, 2021. DOI:10.7591/j.ctvq2vx72.15.

12. Kokobobo, A. 2018. GROTESQUE REALISM AND THE DECLINE OF THE GENTRY IN M. SALTYKOV SHCHEDRIN'S THE GOLOVLEV FAMILY. In Russian Grotesque Realism: The Great Reforms and the Gentry Decline (pp. 78-97). COLUMBUS: Ohio State University Press. DOI:10.2307/j.ctv1grbbrp.8 
Ирина Борисовна Павлова

доктор филологических наук

старший научный сотрудник

Института мировой литературы Российской Академии наук

e-mail: antologia1@yandex.ru

Россия, Москва

ResearcherID AAO-8719-2020

ORCID 0000-0002-0006-0156

DOI: 10.36340/2071-6818-2021-17-1-118-125

\section{ОБРАЗ ПОРОЧНОГО КРУГА В ХУДОЖЕСТВЕННОМ МИРЕ М.Е. САЛТЫКОВА-ЩЕДРИНА}

\begin{abstract}
Аннотация: В статье рассматривается образ-символ порочного круга в творчестве социального сатирика М.Е. Салтыкова-Щедрина. Этот образ играет важную роль в создании картины русского национального мира. Круг воплощает целостность, непрерывность, первоначальное совершенство и - безысходность, фатум, тупик. В произведениях сатирика образ-символ порочного круга несёт значение застоя, безжизненности, отрицания будущего, загадочного предопределения. Применительно к социальной сфере этот образ-символ использован в XIX в. французским социалистом-утопистом Ш. Фурье в труде «Новый хозяйственный и социетарный мир, или изобретение способа привлекательного и природосообразного труда, распределённого в сериях страстей», к нему обращался представитель радикального демократического крыла в русской публицистике Д.И. Писарев (статья «Реалисты»). В произведениях Салтыкова-Щедрина идея порочного круга возникает неоднократно. Сатира «История одного города» свидетельствует, что деспотические формы правления, сменяющие одна другую, власть реакционных тёмных сил являются для страны и народа неким фатумом. Существование представителей поместного дворянства, народных масс движется
\end{abstract}

Салтыкова-Щедрина мы называем писателем «горечи и гнева». Как писал исследователь творчества сатирика С.А. Макашин, «каждый из великих писателей России создал, совокупностью всего написанного им, свой, собственный образ, свою единую и цельную картину родной страны и народа. <...> Все эти и многие другие России были реальностью. Они существовали и сосуществовали. Вместе с ними сосуществовала мрачная, трагическая по замкнутому кругу, отмечено застоем, безнадёжностью, пустотой, отсутствием надежд на будущее. То же можно сказать и о ситуации в русской глубинке: там возможны лишь бессмысленные повторения событий, возобновление тождественных явлений. Консервативно-охранительное стремление мифологизировать историю, апология абсолютизма чреваты опасностью искажения смысла истории, её движущих сил, отрицанием многовековых испытаний, выпавших на долю страны и народа. Образ порочного круга связан для Салтыкова-Щедрина с загадкой русской национальной судьбы, которую он пытался постигнуть на протяжении многих лет. Устремлённость к идеалу социальной гармонии, преодоление замкнутого круга предопределённости для просветителя, моралиста было связано как с общественными преобразованиями, так и с нравственным обновлением личности, с пробуждением Стыда, Совести и Правды в отдельном человеке и в целом обществе, с их духовным преображением, которое дарует возможность совершить прорыв, инициировать целенаправленное животворящее движение вперед.

Ключевые слова: сатира Салтыкова-Щедрина, порочный круг, судьба России, духовное преображение.

Россия Салтыкова, или, лучше сказать, Щедрина, встающая со страниц большинства его произведений...» ${ }^{1}$. При её изображении художник нередко обращался к образу-символу порочного круга.

Значение выражения circulus vitiosus (лат.): логическая ошибка или уловка, при которой

1. Макашин С. Салтыков-Щедрин. Середина пути. 1860-е-1870-е годы. Биография. М., Художественная литература, 1984. С. 426-427. 
какое-либо положение выводится из самого себя, обычно через несколько промежуточных утверждений. Выражение стало фразеологизмом.

Круг - универсальный символ, встречается во многих мировых культурах, религиозных системах, сопровождает всю историю человечества. Заключает в себе идею движения, времени и пространства. Круг - амбивалентен: символизирует целостность, непрерывность, первоначальное совершенство и - безысходность, фатум, тупик, неразрешимую ситуацию.

Во фразеологическом словаре русского языка выражение «порочный круг» объясняется следующим образом: «Слово порочный (от порок) соотносится с религиозно-нравственным кодом культуры, т<о> е<сть> с совокупностью нравственных установок и представлений, в котором порок выступает как нечто позорящее и предосудительное, что даёт повод для негативной оценки в образном содержании фразеол<огизма>.

Фразеол<огизм> в целом отображает стереотипное представление о безысходности стечения обстоятельств, о невозможности найти выход из сложившегося положения.

В других европейских языках есть сходные образные выражения; напр<имер>, во франц.cercle vicieux, в англ. - a vicious circle» 2 .

В данной статье пойдёт речь об использовании этого образа в социальной сатире.

Следует отметить, что в русской литературе и публицистике XIX в. не только Салтыков-Щедрин прибегал к образу-символу порочного круга. Так, его современнику, «радикальному разночинцу» Писареву в статье «Реалисты» (1864) принадлежал афоризм, ставший крылатым: «...мы бедны, потому что глупы, и мы глупы, потому что бедны. Змея кусает свой хвост и изображает собой эмблему вечности, из которой нет выхода. Шарль Фурье говорит совершенно справедливо, что главная сила всех бедствий современной цивилизации заключается в этом проклятом cercle vicieux» ${ }^{3}$. Критик подразумевал работу французского социалиста-утописта «Новый хозяйственный и социетарный мир, или Изобретение способа привлекательного и природосообразного труда, распределённого в сериях страстей» (1829). Фурье называл порочным кругом

2. Захарченко И.В. Порочный круг // Большой фразеологический словарь русского языка. Значение. Употребление. Культурологический комментарий / ред. В.Н. Телия. М.: АСТ-Пресс книга, 2006.

3. Писарев Д. И. Полное собрание сочинений и писем: в 12 т. Т. 6. М.: Наука, 2003. С. 224 буржуазной цивилизации тот факт, что бедность рождается из самого изобилия. В качестве выхода из cercle vicieux он предлагал создание крупного производства, развитие науки и искусства, которые помогут покончить с бедностью и невежеством.

Как было отмечено, этот образ имеет важное значение при формировании концепции русского мира Салтыковым-Щедриным.

Гротескная «История одного города» занимает исключительное место в отечественной классической литературе. Город Глупов символ всей России, «взятой в обличительных сгущениях её реакционных сил и тёмных сторон», её «исторического зла», разлитого во всём «порядке вещей» 4 . Эсхатологический финал сатиры связан с разрушением времени, с «концом». Произведение заканчивается словами: «История прекратила течение своё» ${ }^{5}$. Но если исходить из «пророчества» УгрюмБурчеева: «Идет некто за мною, который будет ужаснее меня» и описи градоначальников, то после исчезновения фанатичного нивелятора в город въезжает Перехват-Залихватский на белом коне, как победитель, сжигает гимназию и упраздняет науки. То есть всё возвращается на кру́ги своя.

Движению по замкнутому кругу подчиняется существование поместного дворянства, описанное в раннем рассказе «Противоречия», во многих сатирических циклах, в хронике «Пошехонская старина», а также жизнь русской глубинки, бесчисленных провинциальных захолустных городков, которые являются «местом циклического бытового времени», по определению М.М. Бахтина. «Тут нет событий, а есть только повторяющиеся «бытования». Время лишено здесь поступательного исторического хода, оно движется по узким кругам <..> > 6 . Везде господствуют скука, безнадёжность, отсутствие живого, активного начала.

В ряде произведений Салтыков-Щедрин проводил мысль, что мифологизация абсолютной власти консервативно-охранительными представителями «государственной» или «либеральной» исторических школ оборачивается фальсификацией, означает отрицание веков тяжких страданий, испытаний, выпавших на долю родины, её

4. Макашин С. Салтыков-Щедрин. Середина пути. 1860-е-1870-е годы. Биография. С. 436.

5. Салтыков-Щедрин М. Е. Собр. соч.: в 20 т. Т. VIII. М.: Художественная литература, 1969. С. 423. В дальнейшем ссылки на это издание даются в тексте с указанием в скобках тома и страницы.

6. Бахтин М.М. Формы времени и хронотопа в романе // Бахтин М.М. Вопросы литературы и эстетики. М.: Художественная литература, 1975. С. 396. 
будущего. В рассказе «Дети Москвы» он вкладывает в уста героя-повествователя, вспоминающего годы, проведённые в привилегированном учебном заведении, следующие слова: «Россия представлялась мне месторождением сказочных витязей, «прекрасных, гордых, величавых», а история её - каким-то светозарным кругом, в котором княжения сменяли друг друга, не оставляя после себя ничего, кроме славы» (XII, 372).

Безысходность определяет и жизнь народных масс. В хронике «Наша общественная жизнь», февраль 1864 года, мифологический образ неумолимого времени - Сатурна делает особенно впечатляющей беспросветную картину народной жизни: «Непроницаемая тьма свинцовым пологом ощетинилась и отяжелела над этими хижинами, и в этой тьме безраздельно царствует старый Сатурн, заживо поедающий детей своих. Сын безотлучный свидетель безмолвного малодушия или трусливого лукавства отца, может ли вынести из своих наблюдений что-нибудь иное, кроме собственного малодушия и лукавства? Сын, от сосцов матери привыкший видеть, что всё вокруг него покоряется слепой случайности, не делая ни малейшей попытки к освобождению себя из-под гнёта её, может ли выработать что-нибудь иное, кроме безграничной веры в ту же слепую случайность? И таким образом переходит она, эта тьма, от одного поколения к другому, все круче и круче закрепляя проклятые тенёта, которыми они спутаны» (VII, 267-268). Салтыкову-Щедрину часто представлялось, что русская жизнь фаталистически движется по замкнутому кругу, который неизвестно, как разорвать, и что гнёт вековых предрассудков всё усугубляется.

Образ порочного круга в щедринской идейнохудожественной концепции связан с загадкой национальной судьбы. Тот мир, который предстаёт в произведениях Салтыкова-Щедрина, до крайности противоречив, неупорядочен, причинноследственные связи запутаны. Всё свидетельствует, что его постижение и преобразование требуют значительных усилий. Размышления писателясатирика на эту тему окрашены глубокой тревогой, исполнены горечи, негодования. Сугубый критицизм не только свойство ума СалтыковаЩедрина - его порождали многие факты и явления современной художнику действительности. «Разве такое общественное устройство, - ставит он вопрос в своих произведениях, - не представляет собой, так сказать, безысходный круг, в котором постоянно возобновляются тождественные явления, без всякой надежды на возможность когда-либо разрешить их?» (V, 372). В этом порочном круге бьётся Россия и не может вырваться на свободу. В творчестве сатирика родина и народ предстают неизменно страдающими от «противоречий» и «запутанных дел», «злосчастья», «тёмного колдовства».

Пути преодоления скорбного удела своей страны писатель-сатирик искал на протяжении всей творческой жизни. Мысль о личной и коллективной ответственности за будущее России постоянно присутствует в его произведениях. Автор ясно представлял всю силу эмпирического зла, общественно-исторических обстоятельств, несовершенство «порядка вещей». Просветитель, социальный моралист Салтыков-Щедрин, деятельность которого пришлась на 1850-1880-е годы XIX в., неустанно искал возможность разорвать замкнутый круг предопределённости. Поэтому идеальная установка его творчества была ориентирована на пробуждение Стыда, Совести и Правды в людях и в целом обществе, на их духовное преображение, которое дарует возможность совершить прорыв, инициировать целенаправленное животворящее движение вперёд. Художник-сатирик твёрдо верил: для разрешения загадки России «надо взять в руки посох, препоясать чресла» и «идти вперед, вышнего града взыскуя» (XIII, 285), как сказано в цикле «Убежище Монрепо» (1878-1879) о неустанном стремлении к социальной гармонии и высшим этическим ценностям.

\section{БИБЛИОГРАФИЯ}

1. Бахтин М. М. Формы времени и хронотопа в романе // Вопросы литературы и эстетики.- М.: Художественная литература, 1975.- С. 234-407.

2. Данилова А.И. Архетипический образ круга в русской литературе // Новороссийский филиал ГОУ
ВПО «Пятигорский гос. лингвистический ун-т.2012. - № 2. - С. 271-274.

3. Макашин С.А. Салтыков-Щедрин. Середина пути. 1860-е-1870-е годы. Биография.-М.: Художественная литература, 1984. 
4. Писарев Д.И. Полн. собр. соч.: в 12 т.- Т. 6.-М.: Наука, 2003.

5. Резникова Е.В. Динамический аспект концепта «круг»: опыт структурирования на основе образсхемы // Вестник Самарского гос. ун-та. История, педагогика, филология / Самарский нац. исследовательский ун-т им. Акад. С. П. Королева. - Самара, 2016. - № 3-2. - С. 162-165.

6. Салтыков-Щедрин М.Е. Собр. соч.: в 20 т.-T. V, VII, VIII, XII, XIII.- М.: Художественная литература, 1965-1977.

7. Сараева Е.Л. Размышления П.Я. Чаадаева о судьбе России // Ярославский педагогический вестник.2014. - № 4. - Т. 1. - С. 17-26.

8. Фразеологический словарь русского языка // Большой фразеологический словарь русского языка. Значение. Употребление. Культурологический комментарий / В. Н. Телия.— М.: АСТ-Пресс книга, 2006.
9. Павлова И.Б. 2020. Символика цвета в произведениях М.Е. Салтыкова-Щедрина», Дом Бурганова. Пространство культуры, Т. 16, № . 2, С. 91-99. DOI:10.36340/2071-6818-2020-16-2-91-99

10. Gerschenkron, A. 1975. Time Horizon in Russian Literature. Slavic Review, 34(4), 692-715. DOI: $10.2307 / 2495723$

11. Lounsbery, Annoncee. «In the End: Shchedrin, Sologub, and Terminal Provinciality. », Life Is Elsewhere: Symbolic Geography in the Russian Provinces, 1800-1917, 22942. Ithaca; London: Cornell University Press, 2019. Accessed March 22, 2021. DOI:10.7591/j.ctvq2vx72.15.

12. Kokobobo, A. 2018. GROTESQUE REALISM AND THE DECLINE OF THE GENTRY IN M. SALTYKOV SHCHEDRIN'S THE GOLOVLEV FAMILY. In Russian Grotesque Realism: The Great Reforms and the Gentry Decline (pp. 78-97). COLUMBUS: Ohio State University Press. DOI:10.2307/j.ctv1grbbrp.8 